\title{
CIVILISATIONAL CONFLICT, RENEWAL, OR TRANSFORMATION: POTENTIAL ROLE OF THE OIC
}

\author{
Abdullahil Ahsan*
}

\begin{abstract}
The Organization of Islamic Cooperation (OIC) came into existence at the end of the $20^{\text {th }}$ century during the Cold War, a period that also witnessed concerns among many Western intellectuals about the decline of the West. By the end of the century and the collapse of the former Soviet Union, the "clash of civilizations" thesis had placed Islamic civilisation at the center of international politics, once again raising questions about world peace and coexistence between civilisations. Could Islamic civilisation as represented by the OIC play a role at this juncture of history? Does it possess the capacity and know-how to meet this challenge? Such questions relate also to ideas of worldview: the Renaissance worldview of the West may be seen to have been tainted by Darwinism and Freudianism while the Islamic worldview appears corrupted by extremism. Can the OIC revive the universal Islamic values such as those upheld by Muhammad Iqbal - the $20^{\text {th }}$ century student of Rumi? Can it do so in the context of tumultuous intra-Muslim relations? These questions frame our discussion in this paper.
\end{abstract}

\section{Introduction}

The Organization of Islamic Cooperation (OIC), formerly known as the Organization of Islamic Conference, was founded in 1969 at an Islamic Summit Conference held in Rabat, Morocco. In a world of nations that appeared to be stuck with a scenario imposed by the Cold War, the OIC emerged with a fresh worldview based on the religious teachings disseminated by the Prophet Muhammad (peace be upon him) in $7^{\text {th }}$ century Arabia. Today, amid an apparent 'clash of civilizations' the OIC stands for contributing "to international peace and security, understanding and dialogue among civilisations, cultures and religions and promote and encourage friendly relations and good neighbourliness, mutual respect and cooperation." Is there a potential for this institution to succeed in achieving this goal? This issue merits more elaboration.

Following World War I, the breakdown of the Ottoman state and the subsequent abolition of the caliphate created great anxiety among Muslim intellectuals, and this increased manifold with the emergence of sovereign Muslim nation-states upon the world stage. Muhammad Iqbal (1877-1938), the $20^{\text {th }}$ century student of Jalaluddin Rumi (1207-1273) who came up with the idea of Pakistan, sought to resolve nascent problems of division within the Muslim Ummah by saying:

For the present, every Muslim nation must sink into her deeper self and temporarily focus her vision on herself alone, until all are strong and powerful to form a living family 
of a republic. A true and living unity, according to the nationalist thinkers, is not so easy as to be achieved by a merely symbolical over-lordship. It is truly manifested in a multiplicity of free, independent units whose racial rivalries are adjusted and harmonised by the unifying bond of a common spiritual inspiration. It seems to me that Islam is neither Nationalism nor Imperialism but a League of Nations which recognised artificial boundaries and racial distinctions for facility of reference only, and not for restricting the social horizon of its members. ${ }^{2}$

This idea of a League of Nations of Muslims was to be realised in the form of the OIC.

The idea of the establishment of the OIC came at a time when Western civilisation was already witnessing a sort of decline such that many insightful observers began to see a choice between civilisational renewal or upheaval at the global level. By the end of the $20^{\text {th }}$ century this took shape in the theory of the clash of civilizations which effectively placed the OIC at centre stage in international politics.

\section{Appearance of the Clash of Civilizations Thesis}

The clash of civilizations thesis emerged in the 1990s at the end of the cold war era in international politics. Toward the end of the 20th century Robert Nisbet wrote his History of the Idea of Progress. ${ }^{3}$ The last chapter of this work, entitled "Progress at Bay", concluded that "the scepticism regarding Western progress that was once confined to a very small number of intellectuals in the nineteenth century has grown and spread to not merely the large majority of intellectuals in this final quarter of the century, but to many millions of other people in the West." ${ }^{\text {N }}$ Nisbet recommended a religious awakening or "even a major religious reformation" to revive faith in and optimism about the progress of Western civilisation. ${ }^{5}$

The subject was of such wide interest that several other scholars were motivated to express themselves. As a result in 1987 Paul Kennedy published The Rise and Fall of the Great Powers. ${ }^{6}$ Even though his approach varied from Nisbet's, he arrived at similar conclusions. He analysed the economic and military changes that took place in the European context since $1500 \mathrm{CE}$ and expressed the view that dominant powers maintained their supremacy in world affairs by keeping a prudent balance between the creation of wealth and military expenditure. The failure to maintain such a balance in modern Europe had caused the fall from supremacy of Spain, the Netherlands, France and Britain at different times in history. This process, in Kennedy's opinion, continued till the middle of the twentieth century. He warned the Cold War rivals - the United States and the USSR - of similar consequences in the later half of the twentieth century. ${ }^{7}$

In 1992 Francis Fukuyama published his controversial book, The End of History and the Last Man in which he defended nineteenth century European optimism 
regarding progress and human nature. He expressed his firm belief that the last man in history, aware of his strengths and weaknesses and of his "perfect rights" and "defective duties," will happily subscribe to the ideas of liberal democracy. He also expressed his firm confidence that "a liberal democracy that could fight a short and decisive war every generation or so to defend its own liberty and independence would be far healthier and more satisfied than one that experienced nothing but continuous peace." "Fukuyama's view of the progress of modern European civilisation seemed to be in direct conflict with Robert Nisbet's views.

Within years Samuel Huntington wrote yet another and even more controversial book, The Clash of Civilizations and the Remaking of World Order, in order to answer the questions he raised earlier on the subject in an article in Foreign Affairs in which he argued that a "clash of civilizations" was taking place in our contemporary times, and that dominant players in world politics needed to understand the nature of this clash. Based on his observations, Huntington made policy recommendations. ${ }^{9}$

The shared subject of interest of all four of the above-mentioned scholars is modern European/Western civilisation, and its future: the civilisation that had witnessed tremendous growth and progress for at least four hundred years was seen to be facing difficulties from the beginning of the 20th century, and historians and philosophers of history were expressing strong concern about its future. Historian E. H. Carr once complained: "The decline of the West has become so familiar a phrase that quotation marks are no longer required." ${ }^{10}$ Although Robert Nisbet and Paul Kennedy only partially agreed with the general theme of the West's decline, they argued that their civilisation needed some remedy for its survival and further progress. However, while Nisbet - an intellectual historian - identifies the need for a religious reformation to remedy the situation, Kennedy - a military-cumeconomic historian - emphasises the need for economic growth to counter the problems faced by modern civilisation. ${ }^{11}$ On the other hand, Francis Fukuyama and Samuel Huntington, both political scientists, seem to be mainly interested in maintaining the supremacy of the United States in contemporary world affairs.

Although European thought had already witnessed some crises during the last two decades of the nineteenth century, serious debate about the fate of Western civilisation really began after World War I. A number of distinguished intellectuals expressed their views on the "degeneration" witnessed within the European society. This debate especially came to the notice of ordinary people when Oswald Spengler (1880-1936), a natural scientist turned historian, published the first volume of his Der Untergang des Abendlandes (The Decline of the West) in 1918. ${ }^{12}$ This work's title implied a shocking conclusion about the fate of European civilisation, for Europeans had very high expectations about for the future. This pre-war optimism is reflected in one of Arnold Toynbee's 
profound observations. Toynbee (1889-1975), who was born in 1889 and was one of the most celebrated historians of the $20^{\text {th }}$ century, gave expression to the optimism of his generation as follows:

[My generation] expected that life throughout the World would become more rational, more humane, and more democratic and that, slowly, but surely, political democracy would produce greater social justice. We had also expected the progress of science and technology would make mankind richer, and that this increasing wealth would gradually spread from a minority to a majority. We had expected that all this would happen peacefully. In fact we thought that mankind's course was set for an earthly paradise, and that our approach towards this goal was predestined for us by historical necessity. ${ }^{13}$

Toynbee's optimism was based on the progress in science and technology that the Western civilisation had achieved till the end of the 19th century. ${ }^{14}$ However, this optimism was shattered by the two world wars. Toynbee completed his voluminous The Study of History in the 1950s. Comparing the twenty-one different world civilisations, he concluded:

If there was any validity in the writer's procedure of drawing comparisons between Hellenic history and Western, it would seem to follow that the Western society must, at any rate, be not immune from the possibility of a similar fate; and, when the writer, on passing to his wider studies, found that a clear majority of his assemblage of civilisations were already dead, he was bound to infer that death was indeed a possibility confronting every civilisation, including his own. ${ }^{15}$

Toynbee's "own civilisation" is the European civilisation which he interchangeably identifies with Western civilisation or Western society. Toynbee held the view that decaying civilisations have been rescued by religions in history. Can religious ideas save today's Western civilisation? Iqbal was perhaps dreaming to achieve this goal. However, this raises problems concerning the understanding of religion in our contemporary world.

\section{The Problem of Defining Religion}

For centuries academicians from various art, literature, humanities and social science disciplines have debated the definition of religion. Theologians, philosophers, artists, poets, historians, psychologists, sociologists and many others have discussed philosophy of religion, psychological explanations of religion and morality, the sociology of religion, religion and culture, religion, ethics and morality, religion and science, and religion and numerous other aspects of human thought and society. After considering several definitions of religion advanced by a number of scholars, The Encyclopedia of Philosophy states, "If we take these definitions as attempts to state necessary and sufficient conditions for something to be religion, it is not difficult to show that none of them is adequate." ${ }^{.16}$ But this 
conclusion creates complexity for students of history and social sciences: How could remain vague such an important aspect of human life?

A first challenging question that arises in this context is whether religion is an absolute phenomenon, i.e., observable occurrence, at all, for discussions about religion often involve metaphysics. While sociologists are reluctant to embark on a discussion of metaphysics, philosophers and theologians have speculated freely on metaphysical links in their understanding of religion. How should a historian or a sociologist approach the subject? What would be the most effective mechanism to study religion? Metaphysical speculation? Examination of the rational and empirical evidence? Or a combination of both? But how does one combine both? The Enlightenment tradition - the tradition that fashioned today's academic disciplines - has effectively established experiment and observation as the elementary foundation for studies in historical and social issues. Could or should social scientists studying history cross the boundary set by the Enlightenment?

In general terms students of history and social sciences must maintain commitment to the principles of experiment and observation as foundations for knowledge. By quoting Father Wilhelm Schmidt from a book published in 1912 Karen Armstrong initiates her story of $A$ History of God saying that, "In the beginning, human beings created a God who was the First Cause of all things and Ruler of heaven and earth." 17 This was a natural outcome of the Enlightenment methodology of finding historical truth. But one would hardly find any observable fact for such an early period in history. Historians relied instead on myths and archaeological evidence for information on the subject. Armstrong says:

A brief look at the EnumaElish [creation myth of ancient Mesopotamia] gives us some insight into the spirituality which gave birth to our own Creator God centuries later. Even though the biblical and Koranic account of creation would ultimately take a very different form, these strange myths never entirely disappeared, but would reenter the history of God at a much later date, clothed in a monotheistic idiom."18

Armstrong, like sociologists, wants to understand religion from the beliefs of followers. But do we really know the beliefs of followers of the founders of ancient civilisations? The founders of those civilisations must have been responsible for ensuring cooperation among people, and without some form of inventiveness no civilisation could have been raised. Without some sort of promising ideas and moral teachings, voluntary human cooperation would probably not have been possible. Of course, human beings have the tendency to exploit other human beings in the name of attractive ideas, including religious ideas. For her part, by quoting anthropologists Armstrong suggests that "In the beginning, therefore, there was One God." When this God became "so distant and exalted," "the High God was replaced by the more attractive gods." ${ }^{19}$ But the 
most challenging aspect of this idea is the fact that the first known lawgiver in history - Hammurabi (r.1795-1750BC) - claimed to have received guidance and laws from divine sources. ${ }^{20}$ Archaeologists have found clay tablets which, they claim, contain Hammurabi's codes. Some tablets contained pictorial depiction of Hammurabi, "the King of Justice", receiving his laws from divinity. When were these clay tablets produced? During the life-time of Hammurabi, or later? If they were produced later, how much later? We don't have answers to these questions. Yet these and similar evidence serve to illustrate the point that some form of belief in spiritual elements constituted the backbone of human existence in early civilisations. How then could a student of history totally ignore metaphysics?

George Sarton in his Introduction to the history of Science included theological studies in the category of pure science. ${ }^{21} \mathrm{He}$ observed that during the European Enlightenment explanation of the belief in supernatural and the impact of that belief in human behaviour theological studies fell from the category of pure science. Immanuel Kant's classification of knowledge had a lasting impact on the understanding of religion in the modern world. Although Kant believed in the human mind having a priori categories, his failure to define the nature of these categories led most philosophers in the $19^{\text {th }}$ century to limit their quest for knowledge to the phenomenal world alone. Since then most definitions of religion confined themselves either to supernatural or to aspects of individual and social behaviour: very little can be found by way of a definition of religion combining beliefs in the supernatural with the impact of such beliefs upon human behaviour. We must scrutinise some of the definitions of religion produced by selected intellectuals and activists, for we take views of these activists seriously due to the social and political implications of their ideas on religion.

Napoleon Bonaparte believed that "Religion is excellent stuff for keeping common people quiet." Karl Marx held the view that "Religion is the sigh of the oppressed creature, the heart of the heartless world, just as it is the spirit of the spiritless situation. It is the opiate of the people." Both definitions here are concerned only about Kant's phenomenal world, and lack the fundamental cornerstone of religious beliefs. Emile Durkheim claims to have integrated the concerns about the sacred when he defined religion saying, "A religion is a united system of beliefs and practices relative to sacred things, that is to say, things set apart and forbidden - beliefs and practices which unite into one single moral community called a Church, all those who adhere to them." One can of course observe practices of the Church and the communities in the phenomenal world, but does Durkheim's "beliefs" in "sacred things" originate in the phenomenal world? Did the deities live in history? What is the relationship between the deities and perception about the deities among their followers? Is it fair to theorise early religions from practices of pagans in the jungle? Durkheim 
doesn't seem to pay much attention to the need for cooperation in foundation of civilisations. How can a student of history ignore the beliefs of early civilisations (at the "theological stage of development" as Auguste Comte called it) which became sources of values and ethics for law in those societies? How should one view the role of religion in early civilisations? Or should one define religion only on the basis of beliefs and experiences during the last few centuries? Do rites and rituals practiced by the Church or similar organised institutions provide enough evidence and criteria for defining religion? How does one explain Biblical Isaiah's criticism of the priests for not caring for morality in daily life? Interestingly Egyptian pharaoh Amenhotep IV, who is also known as Akhenaton, revolted against the organised clergy of his time. So did Socrates in Athens in the $4^{\text {th }}$ century BC. However, the question is whether or not the method of experience and observation totally rejects the Bible and other sacred texts claim to contain divine messages as a source of history? Robert Wright in his The Evolution of God has recently demonstrated by evaluating history that the belief in God is not really outside the scope of observation and experiment methodology. ${ }^{22}$

We shall return to Robert Wright later; at this stage, we argue simply that the Enlightenment tradition did accept the Bible as a valid source for ethics and morality that, it was believed, was necessary for the growth and stability of civilisation. In fact, Western civilisation owes many ideas to the so-called JudeoChristian tradition. Herbert Spencer once said that "Religion is the recognition that all things are manifestations of a Power which transcends our knowledge." However, one must admit that this offers no solution to problems in understanding the role of religion in history.

The historian E.H. Carr, a strong enthusiast of the Enlightenment methodology, believes that "the rationalists of the Enlightenment, who were founders of modern historiography, retained the Jewish-Christian teleological views, but secularised the goal; they were thus enabled to restore the rational character of the historical process itself. History became a matter of progress towards the goal of the perfection of man's estate on earth. ${ }^{23}$ But is this a clear answer to the question of how teachings of the Judeo-Christian tradition relate to historical studies? After critically evaluating the literature on ideas about decline in recent history one author has suggested that, "our real problem is not that our popular culture is filled with obscenities or trivialities, but that no one seems able to present the necessary intellectual grounds for an alternative." ${ }^{24}$ The author, Arthur Herman, blames the nineteenth century social sciences for hosting "deterministic assumptions" that impact the understanding of history. ${ }^{25}$ In our opinion, this seems to be the fundamental problem in understanding the role of religion in history. The problem posed by $19^{\text {th }}$ century social science methodology will be clearer if we take our question to a more specific area of historical studies. The 
deterministic assumption seemed to have become formalised with the introduction of Darwinian assumptions of the origins of man in history.

\section{The Problem of Darwinist View of Man}

Although the idea of evolutionary growth of life on earth had been speculated upon by Greek philosophers, and later by Muslim thinkers, the Darwinian view of evolution dramatically changed the view of man and his place in history. Darwin wrote, "The early forebears of man were ... probably furnished with great canine teeth, but as they gradually acquired the habit of using stones, clubs, or other weapons for fighting with their enemies or their rivals, they would use their jaws and teeth less and less. In this case, the jaws together with the teeth would become reduced in size." Quoting this statement from Darwin's The Descent of Man (1871) one anthropologist says:

These weapon-wielding, bipedal creatures developed a more intense social interaction, which demanded more intellect, argued Darwin. And the more intelligent our ancestors became, the greater was their technological and social sophistication, which in turn demanded an ever larger intellect. And so on, as the evolution of each feature fed on the others. This hypothesis of linked evolution was a very clear scenario of human origins, and it became central to the development of the science of anthropology. ${ }^{26}$

Darwin's views have not only influenced the science of anthropology, they have also influenced the science of history. As E.H. Carr has pointed out, “... Darwin made another scientific revolution; and social scientists, taking their cue from biology, began to think of society as an organism. ...Evolution in science confirmed and complemented progress in history. ${ }^{27}$ But this science failed to comfort social scientists on the question of the origin of man. Darwin's view that the human being is a continuation of the animal kingdom had a severe implication for his society of late nineteenth century Europe. As one observer says, "Darwin deprived people of the privilege of being God's special creation, thereby contributing to the feeling of anxiety that characterises the twentieth century." ${ }^{28}$

This observation was made in the context of Judeo-Christian tradition of Europe which holds the view that human beings are a special creation of God and God had a specific purpose behind this creation. This view also introduced the idea of human accountability which had a direct link to social and political systems in all civilisations in history. However the Darwinist belief shook the foundation of European society in the nineteenth century. The question that arises in this context is whether or not it would be "scientific" for a historian or a social scientist to subscribe to pre-Darwinian ideas, as Europeans had done previously, or if there were any impact at all of pre-Darwinian or post-Darwinian beliefs upon the historian or the social scientist. Let us examine both beliefs in the present context. 
Although Darwin believed that, "there exists a Creator and Ruler of the universe," he claimed that:

There is no evidence that man was aboriginally endowed with the ennobling belief in the existence of an Omnipotent God. On the contrary there is ample evidence, derived not from hasty travelers, but from men who have long resided with savages, that numerous races have existed, and still exist, who have no idea of one or more gods, and who have no words in their languages to express such an idea. ${ }^{29}$

Darwin further argued:

The tendency in savages to imagine that natural objects and agencies are animated by spiritual or living essences, is perhaps illustrated by a little fact which I noticed: my dog, a full-grown and very sensible animal, was lying on the lawn during a hot and still day; but at a little distance a slight breeze occasionally moved an open parasol, which would have been wholly disregarded by the dog, had any one stood near it. As it was, every time that the parasol slightly moved, the dog growled fiercely and barked. He must, I think, have reasoned to himself in a rapid and unconscious manner, that movement without any apparent cause indicated the presence of some stranger living agent, and that no stranger had a right to be on his territory.

The belief in spiritual agencies would easily pass into the belief in the existence of one or more gods. For savages would naturally attribute to spirits the same passions, the same love of vengeance or simplest form of justice, and the same affections which they themselves feel. ${ }^{30}$

Who are these savages that Darwin refers to? Animals like Darwin's "fullgrown and very sensible" dog? Uncivilised naked men in the jungle? Or colonised people in Asia and Africa? Whatever the answer is, his views clearly shook the foundation of religious beliefs in Europe. Darwinian views were adapted by most scholars and scientists in the $19^{\text {th }}$ century, and it was "argued that man is not only continuous with the animal kingdom and subject to the laws of nature; they also asserted that his mental, moral, and spiritual qualities evolved by precisely the same process that gave the eagle its claws and the tapeworm its hooks. ${ }^{\prime 31}$ It is precisely because of this assertion concerning the mental, moral, and spiritual qualities of human beings that Darwinism emerged as a rival to established religions.

Following the Darwinian tradition, when in history books contributions of Hebrew prophets are discussed, they are introduced as if the prophets emerged in history through a natural process without any supernatural intervention. The belief is that Abraham, Moses and other Biblical figures invented their own God and worshipped Him, although according to religious texts and beliefs these historical figures themselves claimed that they were chosen by God, the Creator of the universe, in order to guide mankind. Our concern in this essay is to note that this approach to history writing (including all social sciences) has been accepted as the scientific and rational method, and to ask: Are other methods, i.e., the preDarwinist or the religious methods, totally unscientific and irrational? 
Darwin was not the first European intellectual to deal with the subject of the first man. Before him Enlightenment philosopher Georg W. F. Hegel (1770-1831) worked extensively on the subject. Francis Fukuyama has ably presented the modern European approach to history by summarising the contribution of Hegel. According to Fukuyama:

... [f]reedom and nature are diametrically opposed. Freedom does not mean the freedom to live in nature or according to nature; rather, freedom begins only where nature ends. Human freedom emerges only when man is able to transcend his natural, animal existence, and to create a new self for himself. The emblematic starting point for this process of self-creation is the struggle to the death for pure prestige. ${ }^{32}$

Then Fukuyama continues his argument by raising a few questions:

Is it not possible that the struggle for recognition reflects a longing for self-transcendence that lies at the root not only of the violence of the state of nature and of slavery, but also of the noble passions of patriotism, courage, generosity, and public-spiritedness? Is recognition not somehow related to the entire moral side of man's nature, the part of man that finds satisfaction in the sacrifice of the narrow concerns of the body for an objective or a principle that lies beyond the body? ... Hegel ... understands man as a moral agent whose specific dignity is related to his inner freedom from physical or natural determination. It is this moral dimension, and the struggle to have it recognised, that is the motor driving the dialectical process of history. ${ }^{33}$

Fukuyama refers to Immanuel Kant's (1724-1824) famous question whether or not it was possible to write a Universal History, ${ }^{34}$ and suggests that Hegel responded to this question of Kant:

For Hegel, the primary motor of human history is not modern natural science or the ever expanding horizon of desire that powers it, but rather a totally non-economic drive, the struggle for recognition. Hegel's Universal History ... gives us a broader understanding of man - "man as man" - that allows us to understand the discontinuities, the wars and sudden eruptions of irrationality out of the calm of economic development, that have characterised actual human history. ${ }^{35}$

It is interesting to note that Kant himself ventured into a sketch of the beginning of human history on the basis of the Old Testament. He called this venture a "conjectural beginning of human history." Kant's rational mind justified this conjecture by saying, "what may not legitimately be ventured with regard to the progression of the human actions may be attempted with regard to their first beginning. ${ }^{.36} \mathrm{He}$ continues his argument saying:

... [c]onjectures cannot announce themselves as serious business, but at best only as a permissible exercise of the imagination guided by reason, ... they are no match for a history which reports the same events as an actually recorded occurrence, and which is accepted as such a report; for the latter is examined by standards quite different from those of mere philosophy of nature. But precisely because of this difference, and because I here venture on a mere pleasure trip, I may hope to be favored with the 
permission to use, as a map for my trip - undertaken on the wings of the imagination, albeit not without a clue rationally derived from experience - may take the very route sketched out in that document. ${ }^{37}$

After making his "pleasure trip" based on the map sketched in the Old Testament, Kant goes on to point out certain aspects of human nature in order to understand progression in human history. He says:

An exposition of his [man's] history ... is useful for man, and conducive to his instruction and improvement. It teaches him that he must not blame the evils which oppress him on Providence, nor attribute his own offense to an original sin committed by his first parents. (For free actions can in no aspects be hereditary.) Such an exposition teaches man that, under like circumstances, he would act exactly like his first parents, that is abuse reason in the very first use of reason, the advice of nature to the contrary notwithstanding. Hence he must recognise what they have done as his own act, and thus blame only himself for the evils which spring from the abuse of reason. Once the blame for moral evils is correctly laid where it belongs, the strictly physical evils will hardly add up, in the ledger of merit and guilt, to a balance which is in our favor.

This, then, is the lesson taught by a philosophical attempt to write the most ancient part of human history: contentment with Providence, and with the course of human affairs, considered as a whole. For this course is not a decline from good to evil, but rather a gradual development from the worse to the better; and nature itself has given the vocation to everyone to contribute as much of this progress as may be within his power. ${ }^{38}$

Kant's observations are penetrating. The main thrust of Kant's argument is not just philosophical pleasure, but its importance lies in real life; Kant is mainly interested in instructions for the improvement of human life. Clearly both Kant and Hegel viewed the human role in history differently than did Darwin. But with the passage of time the Darwinian view of man totally captured social science literature.

\section{Freudian View of Religion and the First Man}

Sigmund Freud (1856-1939) seemed to have endorsed Marxist phraseology regarding religion and on that basis predicted its future. ${ }^{39}$ An unbeliever, as his translator and biographer called him ${ }^{40}$ Freud tried to comprehend the origin of religion from his knowledge of history and what he called the science of psychology. He believed that religion originated in history out of man's perplexity and helplessness in the face of nature's dreaded forces. He says, "I have tried to show that religious ideas have arisen from the same need as have all the other achievements of civilisation: from the necessity of defending oneself against the crushing superior force of nature." ${ }^{\prime 1} \mathrm{He}$ continues, suggesting that "this body of religious ideas is usually put forward as a divine revelation. But this presentation of it is itself a part of the religious system, and it entirely ignores the known historical development of these ideas and their differences in different epochs and civilisations." ${ }^{42}$ 
Referring to his earlier work on the origin of child's fear of father in Totem and Taboo (1913) psycho-analyst Freud says:

When the growing individual finds that he is destined to remain a child for ever, that he can never do without protection against strange superior powers, he lends those powers the features belonging to the figure of his father; he creates for himself the gods whom he dreads, whom he seeks to propitiate, and whom he nevertheless entrusts with his own protection. Thus his longing for a father is a motive identical with his need for protection against the consequences of his human weakness. The defence against childish helplessness is what lends its characteristic features to the adult's reaction to the helplessness which he has to acknowledge - a reaction which is precisely the formation of religion. ${ }^{43}$

Freud raises interesting questions about authenticity of religions. He says:

When we ask on what their claim to be believed is founded, we are met with three answers, which harmonise remarkably badly with one another. Firstly, these teachings deserved to be believed because they are already believed by our primal ancestors; secondly, we possess proofs which have been handed down to us from those same primeval times; and thirdly, it is forbidden to raise the question of their authentication at all. In former days anything so presumptuous was visited with the severest penalties, and even to-day society looks askance at any attempt to raise the question again. ${ }^{44}$

Freud made these observations as a believer in the Enlightenment philosophy, but unlike most Enlightenment philosophers he did not believe in any role of God in the process of creation. Yet he tried to conceptualise a believer's belief in God, and he attempted to do so by subscribing totally to the Enlightenment methodology - experiment and observation - as the foundation of his own belief.

Freud seems to have believed mainly in two sources for his knowledge of religion and society: one is history and the other is the human nature which he tried to understand scientifically. On history he says, "[t]he less a man knows about the past and the present the more insecure must prove to be his judgment of the future. ${ }^{\prime 45}$ But his understanding of history seems very shallow: He doesn't know the beginnings of any civilisation in history. Citing problems of relying on information from history he accuses religions of imposing restrictions on raising questions about validity of doctrines. He says:

We ought to believe because our forefathers believed... The proofs they have left us are set down in writings which themselves bear every mark of untrustworthiness. They are full of contradictions, revisions and falsifications, and where they speak of factual confirmations they are themselves unconfirmed...

Thus we arrive at the singular conclusion that of all the information provided by our cultural assets it is precisely elements which might be of the greatest importance to us and which have the task of solving the riddles of the universe and of reconciling us of the sufferings of life - it is precisely those elements that are the least authenticated of any. ${ }^{46}$ 
He then depicts religion as illusion which, according to him, is "derived from human wishes" and is a kind of "psychiatric delusions." ${ }^{47}$ However, Freud recognises that "religion has clearly performed great services for human civilization." ${ }^{48}$ Freud, a medical doctor who instituted the psycho-analysis school of psychology, sought to understand history and civilisation through "the characteristic features of civilization...the manner in which the relationships of men to one another, their social relationships, are regulated - relationships which affect a person as a neighbour, as a source of help, as another person's sexual object, as a member of a family and of a state." ${ }^{49} \mathrm{He}$ also suggests that, "the first requisite of civilization, therefore, is that of justice - that is, the assurance that a law once made will not be broken in favour of an individual. $"{ }^{50}$

It is also interesting to note that although Freud recognises the role of justice to be crucial in the formation of civilisations, he doesn't find any role for religious ideas in establishing civilisations in history. Most religions claim justice as one of the cornerstones of faith, and, as we have noted in the introduction of this article, it is universally agreed that religious ideas have played a most significant role in all civilisations in history. However, Freud both recognises and ridicules the existence of the so-called golden rule "Thou shalt love thy neighbour as thyself" from the pre-Christian era. ${ }^{51} \mathrm{He}$ believes that "every individual is virtually an enemy of civilization," 52 and says that "civilization is something which is imposed on a resisting majority by a minority which understood how to obtain possession of the means to power and coercion." ${ }^{33}$ It is here that one sees the shallowness of Freud's knowledge and understanding of history. Historians of civilisations generally agree that human cooperation results in the growth and progress of civilisations and lack of cooperation leads civilisations into decline.

\section{Impacts of Darwinian and Freudian View of Man in Understanding History and Society}

Let us now analyse the impact of Freudian and Darwinian views of the origin of human history. What was the nature of the first man? It is interesting to note that most Enlightenment philosophers were concerned about the nature of the first man, but post-Darwinian scholars have generally believed that human history originated with the transformation of a group of individuals from one form of creation to another. Summarising the concern of pre-Darwinian philosophers on the issue Fukuyama points out:

Hegel in the Phenomenology of Mind described a primitive "first man" living at the beginning of history whose philosophical function was indistinguishable from the "man in the state of nature" of Hobbes, Locke, and Rousseau. That is, this "first man" was a prototypic human being, possessing those fundamental human attributes that existed prior to the creation of civil society and the historical process. ${ }^{54}$ 
But post-Darwinian scholars on the subject attempted to be more specific about evolution of man, both in terms of time and his nature. One anthropologist suggests:

According to the analyses, modern humans can trace their genetic ancestry to a female who lived in Africa perhaps 150,000 years ago. (It should be borne in mind, however, that this one female was part of a population of as many as 10,000 individuals; she was not a lone Eve with her Adam. $)^{55}$

This anthropologist also suggests that "the evolutionary activity giving rise to modern humans (like us) took place in the interval between half a million years ago and 34,000 years ago," 56 and "7 million years ago humans and chimpanzees shared a common ancestor." ${ }^{57}$ Such a long view of human history creates many problems. For example, did human history originate with the "first man" of Hegel or Adam of the scriptures? Or did it originate with as many as 10,000 individuals? Also if we consider the invention of writing as the landmark for the rise of civilisation as 'history proper', then pre-civilisational history constitutes 99.8 percent of human existence. ${ }^{58}$ In other words, we have access only to a very limited portion of historical knowledge. Can such a long view of history be really useful in the study of history? Is it fair to theorise human behaviour on the basis of only 0.2 percent period of human history? Anthropologists argue that the nature of the human being has changed during the earlier phase of human history; he has gradually developed the brain and intellectual capacity to know himself and the environment around him. If man gradually achieved these abilities, then what was the nature of the first man that enabled human beings help achieve this? When did he achieve the potential to grow and develop intellectually? These are important questions for understanding change in human history.

Why is it important to understand the nature of the first man? Why is it important to identify the origin of human history? They are important because in history we are basically interested in human history and also because an understanding of human nature better enables us to comprehend human action and consequently change in human history. ${ }^{60}$ Was the first man free to choose for himself? Did he have the potential to be civilised? From the Darwinian perspective there does not seem to be a clear answer: it seems, as Francis Fukuyama has pointed out that, in the beginning there was a struggle for recognition, and in competition with animals around it the first man, along with its other companions, was able to establish its domination over others. However, this view does not explain, for example, how and why man succeeded in this struggle and the chimpanzees failed. Anthropologists have tried to explain how the first man developed his mind and language. ${ }^{61}$ But why did the chimpanzees fail to develop human-like language and mind? Most of these studies raise more questions about the process of the development of human intellect and language than they answer.

Both Darwinian and Freudian views are hypothetically scientific, but they do not satisfy the inquisitive mind. Interestingly Emergent Evolutionism, a 
philosophical school developed within the tradition of Darwinism, maintains that sudden modifications in the creation of organic beings must be discontinuous with what went before. Whatever comes to be for the first time must do so suddenly and abruptly. ${ }^{62}$ This means, even if human beings emerged from the sub-human state of chimpanzee-like animals, the emergence of the first man must have been discontinuous with his previous state of being. Would it then be proper to suggest that this change was a sort of innovatory rather than evolutionary change? If so, what caused this change? From the religious point of view this change has occurred because of God's intervention in history. But this theme would also raise many questions. Did God intervene only once in initiating the process of creation? Or does God continue to intervene in history by sending prophets? Could miracles be considered God's intervention in history? If so how does one distinguish between miracle and magic? Here appears one very important question: how does one reconcile between science and religion.

Michael Dowd in his Thank God for Evolution: How the Marriage of Science and Religion Will Transform Your Life and Our World has tried to resolve the question by explaining the reason for undertaking the work. ${ }^{63}$ A number of Nobel Laureates (winning the prize in Medicine, Physics and Economics) have highly recommended his work. But the problem still persists. The issue is important because traditionally education systems defined their aim and purpose as preparing good human beings and good citizens. However, the Enlightenment tradition rejected the religious view of the aim of education - the idea of a purpose for creation lost credibility in educational systems. Later Napoleon Bonaparte, a practicing Deist, introduced the aim of education as producing capable officials for his administration. The Napoleonic education system was later adopted by most nation-states in the modern world. As a result the modern educational system lost connection with moral and ethical values. One observer describes this development as follows:

Most philosophers [of the Enlightenment] were deists who tried to make religion compatible with a scientific understanding of nature. Deists believed only those Christian doctrines that could meet the test of reason. For example, they considered it reasonable to believe in God, for only with a creator, they said, could such a superbly organised universe have come into being. But after God set the universe in motion, said the deists, he took no further part in its operations. Thus, while deists retained belief in God the Creator, they rejected clerical authority, revelation, original sin, and miracles. ${ }^{64}$

Even Immanuel Kant's prescription for accepting certain aspects of the revelation in identifying the origin of human history, was rejected. Historians and social scientists were not willing to accept the validity of revelation and God's intervention in history by guiding humanity through offices of prophets. 
Later scholars of Darwinism (and social scientists) began to view revelations and miracles equivalent to myths. Gradually revelation lost respect as a source of knowledge, although it had served as a valid source of knowledge until the $18^{\text {th }}$ century, George Sarton recorded in his An Introduction to History of Science. Now the question is how to rationally introduce the idea of revelation as a valid source of knowledge. Should revelation be introduced in history and social science literature as a source of knowledge for governing human societies?

\section{Revelation as a Source of Knowledge for Governing Societies}

The question of introducing revelation as a valid source of knowledge has been debated extensively in recent times. We shall highlight ideas advanced by two scholars: One by a physicist, and the other by a historian. Charles H. Townes, a Nobel Prize winner in Physics, first critically evaluated $19^{\text {th }}$ century science and then made recommendations in favour of revelation. He says:

The march of science during the $19^{\text {th }}$ century produced enormous confidence in its success and generality. ... Scientific laws appeared to take on an absolute quality, and it was very easy to be convinced that science would explain everything. ... Toward the end of the $19^{\text {th }}$ century, many physical scientists viewed their work as almost complete and needing only some extension and more detailed refinement. ${ }^{65}$

Then he wonders, "How wrong, oh how wrong were many ideas which physicists thought were so obvious and well-substantiated at the turn of the century!" then continues suggesting the convergence of science and religion as saying:

The goal of science is to discover the order in the universe and to understand through it the things we sense around us, and even man himself. This order we express as scientific principles or laws, striving to state them in the simplest and yet most inclusive ways. The goal of religion may be stated, I believe, as an understanding (and hence acceptance) of the purpose and meaning of our universe and how we fit into it. Most religions see a unifying and inclusive origin of meaning, and this supreme purposeful force we call God. ${ }^{67}$

Townes concludes his argument with a positive note, he says:

Perhaps by the time this convergence occurs, science will have been through a number of revolutions as striking as those which have occurred in the last century, [he published this article in 1966] and taken on a character not readily recognisable by scientists of today. Perhaps our religious understanding will also have seen progress and change. But converge they must, and through this should come new strength for both. ${ }^{68}$

But ultimately the idea of the separation of church and politics has been understood to mean that religious ideas must have no role to play in comprehending human nature and governance of human society. 
For his part historian Robert Wright, whom we have encountered earlier in this essay, summarises the human desire for God throughout human history and finds historical evidence of a consistent evolution of God in history. In the introductory chapter of his book The Evolution of God Wright begins with descriptions of rituals of what he calls "the primordial faith" of certain tribal communities and says that, "...over the time there has been - on balance, taking the long view - a pattern in the change. Religion has gotten closer to moral and spiritual truth, and for that matter more compatible with scientific truth." ${ }^{\circ 9}$

Wright also argues that with the passage of time this pattern has brought religions closer to modernity. With the progressive growth of human intellect religions began to advance rational and scientific arguments as "signs" for sceptics. "Muhammad, unlike the biblical Jesus and Moses, doesn't depend on miracle-working for proof of proximity to God." ${ }^{\prime 70}$ After citing Qur'anic passages' explaining empirically verifiable "signs", Wright says:

This amassing of evidence of God's goodness and grandeur makes the Koran come much closer than the Bible to fitting the description Darwin gives to his book The Origin of Species: "one long argument." That's not the only thing the two books have in common. Both arguments purport to explain the exquisitely fine fit between humans and their natural surroundings. Muhammad notes how conducive the ecosystem is to human flourishing and explains it via God's design of the ecosystem. Darwin notes the same close match between humans and their ecosystem and posits a different explanation: humans were shaped to fit their ecosystem - not the other way around. ${ }^{71}$

However this apparent positive view about the growth and maturity of religion does not resolve the question of a fair understanding of religion in society today. If religion is meant to be guidance for people, as many religions have claimed, and, as Wright says, "Religion needs to mature if the world is going to survive,", 72 then the question is how should one seek guidance from religion. How does one determine what is divine and what is verging upon human exploitation in the name of religion.

Wright has noted that, "In Polynesia the chief used his divine authority for typical chiefly endeavors: organising feasts, organising armies, maintaining roads and irrigation systems - and amassing the requisite resources... modern politicians manage to do the same thing... without being thought even remotely sacred." ${ }^{\prime 73}$ The question therefore is that how does one scrutinise the validity of what appears in religious texts. How to evaluate whether the ideas recorded in these books existed in the original text or they were later inserted by holders of religions. Robert Wright documents an interesting point. According to him, Jesus didn't really say "Love your enemies." "This was inserted in scripture decades after crucifixion." Paul added this perhaps because he as a part of religious minority "could be persecuted to the point of extinction." " ${ }^{\text {" }} \mathrm{But}$ as a result of this apparent 
positive motive of Paul, the religious text lost its universal value. Therefore the question is how to decipher the real divine guidance in these teachings. Here, in our opinion, appears the most crucial role of science and humanism and religion. Can humanity develop an acceptable methodology in this regard? Is it possible for the humanity to revive a methodology similar to that of the Renaissance prior to the Enlightenment? Can humanity save itself from the $19^{\text {th }}$ century deviation from religion and seek knowledge for establishing peace in society? Will humanity utilise its scientific gains for a better and relevant understanding of divine guidance? Will scientific disciplines such as cognitive neuroscience, behavioural genetics, evolutionary psychology and evolutionary psychology, which have identified many aspects of the human nature hard wired in the human brain, play any role in addressing these questions? These are some challenges for humanity today. And in order to encounter these challenges humanity needs to build up a positive approach toward divine guidance and develop an acceptable and rational methodology to achieve this goal.

\section{Potentials for Muslim Contribution to Avert the Current Crisis}

Among religious texts the Qur'an is the only book which has not changed from its original structure and language. Its prophet Muhammad is a historical figure and the Qur'an was recorded during his lifetime and there is no disagreement among Muslims on the text of the Qur'an. Also the Qur'an rationally answers objections against religious ideas raised by Freud. However, should Islam be able to contribute anything on the question of how to save a decadent civilisation, then why it hasn't done so to save its own? This is a valid question. The Qur'an claims to be a book of guidance for mankind (2:185). From the Qur'anic perspective, human beings have not been created with any inherent taint of sin; rather, man was created in the best of moulds (95:4) and God breathed His Own spirit into him (15:29, 38:72). The Enlightenment philosophers debated this issue without reaching any consensus. The Qur'an suggests that an innate goodness has been ingrained into the human nature, but human beings are also prone to make mistakes and commit sins. This is because along with goodness, they have also been created as covetous, forgetful, greedy and weak. ${ }^{75}$ The Qur'an seems to suggest a pathway of human life that lies between the ideas of Rousseau (17121778) and Edmund Burke (1729-1797). According to the Qur'an, life is meant to test human beings whether they act positively and contribute to human civilisation or act negatively and harm civilisation. During the past two hundred years social sciences have made significant advancements in understanding human nature. Shouldn't the social scientists now re-evaluate their findings in the light of the fate of the Western civilisation on the one hand and the Qur'anic teachings on the other? 
It is interesting to note that even though social scientists have generally considered religion to be an individual matter, historians have identified the prominent role of religion in all civilisations throughout history. At the same time some other historians have also been sceptical about the usefulness of religion's role because of the exploitation of religious ideas by vested interests who blur the distinction between truth and falsehood: "And mix not truth with falsehood, nor conceal the truth while you know," says the Qur'an (2:42) and "... woe be to those who write the book with their own hands, and then say: 'This is from Allah,' to traffic with it for a miserable price..." (2:79). As for the Qur'an, it puts the responsibility to save the civilisation on mankind's shoulders alone: for God does not change the condition of a people until they change what is in themselves (13:11).

\section{Potential Role of the OIC}

Why should the OIC seek to undertake to play a role in the enormous task of civilisational renewal? As a legitimate international governmental organisation with 57 member states only second to the United Nations, the OIC may indeed represent an opportunity to demonstrate that Islamic ideas are capable of offering guidance to humanity at our current historical juncture. At a time when many people are disappointed and even frustrated with religions, particularly in the West, the OIC has the potential to demonstrate positive Islamic values in providing guidance to various segments of socio-political and economic developments in the world today.

Most observers of international affairs believe that the 2008 global economic crisis occurred due to a collapse of values. Can the OIC play any role in addressing this question? An Islamic economic alternative to Western conventional economic system began to emerge during the fourth quarter of the last century and some OIC affiliated institutions have participated in the process. Although Islamic financial institutions have gained popularity with the passage of time, they were hardly proven effective in responding to or averting the 2008 global economic crisis. If the OIC could exhibit stronger political will than it has in recent decades, and were it to embark upon an intensive campaign of action-oriented research, it might be able to achieve a breakthrough in averting such catastrophic situation, and so redeem itself as an institution truly capable of civilisational renewal.

The clash of civilization thesis, the 9/11 attacks and the war on terror have become common currency in discussions of international relations today. International peace and security concerns are major concerns of the day. In our view an effective OIC should have the capability to contribute positively in this regard: during the Iran-Iraq war in the 1980s the OIC discussed the possibility of creating an Islamic peace keeping force but it never materialised. In our opinion, an Islamic peace keeping force would have been more effective than the NATO 
troops in Afghanistan today. The same could have been possible in Iraq where extremists would not have been able to depict a contingent of OIC troops as "occupying forces". The OIC should bring its resources to address any and all of the conflicts raging in the Muslim world today.

\section{Conclusion and Policy Recommendations}

On top of these political and economic issues the OIC is already purportedly addressing many issues such as collective economic and financial growth of states ostensibly serving Muslims all over the world. Much more can be done to promote education, scientific and technological advancement, an enhanced role for women in society, actions to eradicate gross human rights violations, effective roles for civil society groups, humanitarian assistance for refugees and other steps to meet key areas of urgent need around the world. More effective and successful outcomes in all of these activities would definitely contribute toward a better world tomorrow, and qualify the OIC as an effective proponent of civilisational renewal.

So our recommendations would be:

- The OIC should establish an independent think-tank to address the question of civilisational crisis and its transformation in the world today.

- The confusion within Western "scientific" methodology in understanding history and civilisation should be addressed academically and Qur'anic values which might provide useful guidance in achieving this goal should be elaborated, studied and put into practice.

- Institutional good governance certification can only be accorded to institutions when they evidence clearly that they subscribe to universal human values such as individual dignity and justice.

\section{Notes}

* Abdullahil Ahsan is professor at International Institute of Islamic Thought and Civilization (ISTAC), International Islamic University Malaysia. His works include: The Organization of the Islamic Conference: Introduction to an Islamic Political Institution (1988) and Ummah or Nation: Identity Crisis in Contemporary Muslim Society (1992). He is currently working on Muslim Nations in Contemporary History and Rise and Fall of Civilisations.

1. http://www.oic-oci.org/oicv2/page/?p_id=53\&p_ref=27\&lan=en

2. Muhammad Iqbal, The Reconstruction of Religious Thought in Islam (Reprinted New Delhi: Kitab Bhaban, 1981), 159.

3. Robert Nisbet, History of the Idea of Progress (New York: Basic Books, 1980).

4. Ibid., 317.

5. Ibid., 357.

6. Paul Kennedy, The Rise and Fall of the Great Powers: Economic Change and Military Conflict from 1500 to 2000 (New York: Vintage Books, 1989). 
7. See, ibid., "Epilogue," 536-540.

8. Francis Fukuyama, The End of History and the Last Man (New York: The Free Press, 1992), 329.

9. See, Huntington, "Preface," in The Clash of Civilizations and the Remaking of World Order. (New York: Simon Schuster, 1996), 13-15.

10. See, E. H. Carr, What is History? $2^{\text {nd }}$ ed. (London: Penguin Books, 1987), 112.

11. See, Nisbet, History of the Ideas of Progress, 352-357; and Kennedy, The Rise and Fall of the Great Powers, 413-535.

12. Oswald Spengler, The Decline of the West, 2 vols. trans. Charles Francis Atkinson (New York: Alfred A. Knopf, 1922).

13. Arnold Toynbee, Surviving the Future (New York: Oxford University Press, 1971), 106-107.

14. This optimism is also reflected in the statement by the captain of Titanic, which sank in 1912, that, "This ship can't sink."

15. Arnold J. Toynbee, A Study of History, abridgement by D.C. Somervell (London: Oxford University Press, 1960), 912.

16. William P Alston, "Religion," Encyclopedia of Philosophy, 7: 140.

17. Karen Armstrong, A History of God: The History of God: The 4000-Year Quest of Judaism, Christianity and Islam. (NY: Alfred A Knopf, 1994), 3.

18. Ibid. 7.

19. Ibid. 3.

20. On Hammurabi see, Joyce O. Hertzler, The Social Thought of the Ancient Civilizations. (NY: McGraw-Hill, 1936). 85ff.

21. George Sarton, An Introduction to History of Science. 3 vols. (Washington: Carnegie Foundation, 1929).

22. Robert Wright, The Evolution of God. (NY: Little, Brown and Company, 2009).

23. Carr, 110-111,

24. Arthur Herman, The Idea of Decline in Western History (New York: The Free Press, 1997), 450-51.

25. Ibid., 448.

26. Richard Leaky, The Origin of Humankind. (London: Wedienfeld \& Nicolson, 1994), 3-4.

27. Carr, 56-57.

28. Marvin Perry, 549.

29. Charles Darwin, The Descent of Man and Selection in Relation to Sex. Great Books of the World: 49. (Chicago: Encyclopedia Britannica, 1990), 302.

30. Ibid., 303.

31. Morton O. Beckner, Encyclopedia of Philosophy, "Darwinism."

32. Francis Fukuyama, The End of History and the Last Man. (NY: The Free Press, 1992), 152. (The italics are original).

33. Ibid., 161.

34. Fukuyama refers to Immanuel Kant, "Idea for a Universal History from a Cosmopolitan Point of View" in On History. (New York: Macmillan, 1963), 11-26.

35. Fukuyama, 135.

36. Kant, "Conjectural Beginning of Human History" in On History. 53

37. Ibid., 53-54.

38. Kant, 68.

39. Sigmund Freud, The Future of an Illusion. Translated and edited by James 
Strachy. (New York: W.W. Norton, 1961).

40. Ibid., xi

41. Ibid., 26-27.

42. Ibid., 27.

43. Ibid., 30 .

44. Ibid., 33.

45. Ibid., 5.

46. Ibid., 33-34.

47. Ibid., 39.

48. Ibid., 47.

49. Sigmund Freud, Civilization and its Discontents. (NY: W.W. Norton, 1930), 41-42.

50. Ibid.

51. Ibid., 56.

52. Freud, Illusion, 6.

53. Ibid., 7.

54. Fukuyama, 146.

55. Leaky, 96.

56. Ibid., 82-83.

57. Ibid., 153.

58. See S. J. De Laet, History of Humanity. Seven volumes, Pre-history and the Beginning of Civilization. (New York: Routledge, 1994), 1: 2. According to this author human history began sometime about 2.3 million years ago.

59. See Albertine Gaur, A History of Writing. Rev. ed. (London: The British Library, 1984, 1992), 18.

60. On this subject, see Leon Pompa, Human Nature and Historical Knowledge Hume, Hegel, and Vico. (Cambridge: Cambridge University Press, 1990).

61. See Leaky, "The Origin of Mind," in The Origin of Humankind: 119-157 and John E. Pfeiffer, The Emergence of Man. (London: Book Club Associates, 1973), 392-435.

62. Goudge, T. A., "Emergent Evolutionism," q.v. The Encyclopedia of Philosophy.

63. Michael Dowd, Thank God for Evolution: How the Marriage of Science and Religion Will Transform Your Life and Our World. (NY: Viking; 2007), 1-2.

64. Perry, 400.

65. Charles W. Townes, "The Convergence of Science and Religion," in Think, (Published by IBM), Vol. 32, No. 2, 1.

66. Ibid., 4.

67. Ibid.

68. Ibid., 7.

69. Wright, 9-28.

70. Ibid., 397.

71. Ibid., 398-399.

72. Ibid., 28.

73. Ibid., 54.

74. Ibid., 284-285.

75. See "Qur'anic Guidance on Good Governance," in Abdullah al-Ahsan and Stephen B. Young, eds. Guidance for Good Governance: Explorations in Qur'anic Scientific and Cross-cultural Approaches (Kuala Lumpur: International Islamic University Press, 2008), 9-37. 